\title{
Genetic and expression alterations in association with the sarcomatous change of cholangiocarcinoma cells
}

\author{
Hee-Jung Yoo ${ }^{1}$, Bo-Ra Yun ${ }^{1}$, \\ Jung-Hee Kwon ${ }^{2}$, Hyuk-Soo Ahn', \\ Min-A Seol ${ }^{1}$, Mi-Jin Lee, ${ }^{1}$ \\ Goung-Ran $\mathrm{Yu}^{1}$, Hee-Chul $\mathrm{Yu}^{3}$, \\ BeeHak Hong ${ }^{2}$, KwanYong Choi ${ }^{2}$ \\ and Dae-Ghon Kim ${ }^{1,4}$

\section{${ }^{1}$ Division of Gastroenterology and Hepatology \\ Department of Internal Medicine} \\ Institute for Medical Sciences \\ Chonbuk National University Medical School and Hospital \\ Jeonju 561-712, Korea \\ ${ }^{2}$ Department of Life Sciences \\ Pohang University of Science and Technology \\ Pohang 790-784, Korea \\ ${ }^{3}$ Department of General Surgery \\ Chonbuk National University Medical School and Hospital \\ Jeonju 561-712, Korea \\ ${ }^{4}$ Corresponding author: Tel, 82-63-250-1681; \\ Fax, 82-63-254-1609; E-mail, daeghon@ chonbuk.ac.kr \\ DOI 10.3858/emm.2009.41.2.013
}

\section{Accepted 3 November 2008}

Abbreviations: CC, cholangiocarcinoma; Dox, doxorubicin; EMT, epithelial mesenchymal transition; FDR, false discovery rate; FHIT, fragile histidine triad; KRTs, keratins; SAM, significance analysis of microarray

\footnotetext{
Abstract

Cholangiocarcinoma (CC) is an intrahepatic bile duct carcinoma with a high mortality rate and a poor prognosis. Sarcomatous change/epithelial mesenchymal transition (EMT) of CC frequently leads to aggressive intrahepatic spread and metastasis. The aim of this study was to identify the genetic alterations and gene expression pattern that might be associated with the sarcomatous change in CC. Previously, we established 4 human CC cell lines (SCK, JCK1, Cho-CK, and Choi-CK). In the present study, we characterized a typical sarcomatoid phenotype of SCK, and classified the other cell lines according to tumor cell differentiation (a poorly differentiated JCK, a moderately differentiated Cho-CK, and a well differentiated Choi-CK cells), both morphologically and immunocytologically. We further analyzed the genetic alterations of two
}

tumor suppressor genes ( $p 53$ and $F H I T$ ) and the expression of Fas/Fas $L$ gene, well known CC-related receptor and its ligand, in these four $\mathrm{CC}$ cell lines. The deletion mutation of $p 53$ was found in the sarcomatoid SCK cells. These cells expressed much less Fas/FasL mRNAs than did the other ordinary CC cells. We further characterize the gene expression pattern that is involved in the sarcomatous progression of $\mathrm{CC}$, using cDNA microarrays that contained 18,688 genes. Comparison of the expression patterns between the sarcomatoid SCK cells and the differentiated Choi-CK cells enabled us to identify $\mathbf{2 6 0}$ genes and $\mathbf{2 4 7}$ genes that were significantly over-expressed and under-expressed, respectively. Northern blotting of the 14 randomly selected genes verified the microarray data, including the differential expressions of the LGALS1, TGFBI, CES1, LDHB, UCHL1, ASPH, VDAC1, VIL2, CCND2, S100P, CALB1, MAL2, GPX1, and ANXA8 mRNAs. Immunohistochemistry also revealed in part the differential expressions of these gene proteins. These results suggest that those genetic and gene expression alterations may be relevant to the sarcomatous change/EMT in CC cells.

Keywords: cholangiocarcinoma; gene expression profiling; oligonucleotide array sequence analysis; sarcoma

\section{Introduction}

Cholangiocarcinomas (CC) are primary malignancies of the biliary tract, and patients with these tumors have a poor prognosis because it is difficult to make an early diagnosis and the standard therapy is not very effective (Ahrendt et al., 2001). Chronic biliary tract inflammation resulting from bacterial infection or parasitic infestation or from a chronic inflammatory disease such as primary sclerosing cholangitis predisposes a patient to the development of CC (Chang et al., 1983). Most hepatic tumors with sarcomatous features are sarcomatoid carcinomas, whereas true hepatic sarcomas are extremely rare tumors (Kakizoe et al., 1987). These sarcomatoid cells are the result of a reversal of differentiation of ordinary hepatocellular carcinoma cells or adenocarcinomatous CC cells (Oda et al., 1994). Such tumors are predominantly composed of spindle-cell, giant cells 
and bizarre cells that express cytokeratins (KRTs) as an epithelial marker and vimentin as a mesenchymal marker. It has been suggested that this tumor has an epithelial origin and it is then transformed to the sarcomatous type. The incidence of sarcomatous change in CC is approximately $5 \%$. However, patients with these tumors show aggressive intrahepatic spread of tumor and widespread metastasis, and they have a poorer prognosis than those patients with ordinary CC. Epithelial tumor cells lose their restriction during the last steps of tumorigenesis, concomitant with the loss of epithelial characteristics and the acquisition of motile behavior. These changes contribute to a transition from an epithelial morphology toward a more mesenchymal fibroblastic (sarcomatoid) phenotype, and this is referred to as epithelial to mesenchymal transition (EMT) (Boyer et al., 1997).

The molecular mechanism whereby cancer cells generate a cell-autonomous EMT-like process via oncogenic activation is still unclear. One approach to understanding how genetic and molecular changes can lead to EMT is to compare the gene expression between tumor cells with EMT and the paired tumor cells without EMT. cDNA microarray is a well established technique to perform largescale surveys of the expression of genes and to identify candidate target genes. We previously established four distinct CC cell lines (SCK, JCK1, Cho-CK, and Choi-CK) and we analyzed their chromosomal aberrations by cross-species color banding (Kim et al., 2001). One of them (SCK) was derived from the sarcomatoid CC. In this study, we verified the grade of differentiation in the four cell lines using a xenotransplanted nude mice model and examined a typical sarcomatoid phenotype of SCK cells both morphologically and immunocytologically. We further analyzed the status of tumor
A

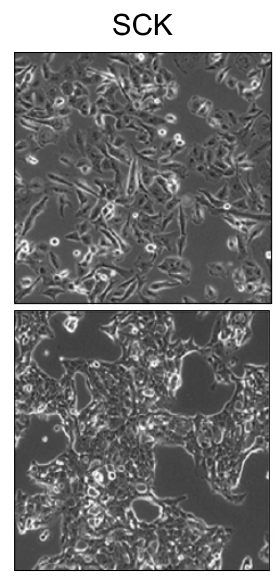

Cho-CK
B

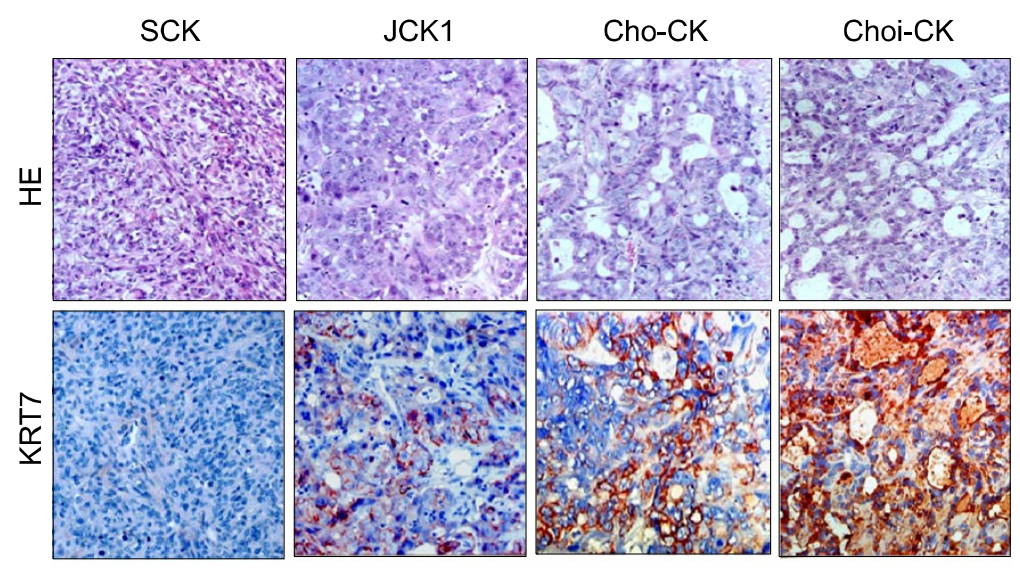

C

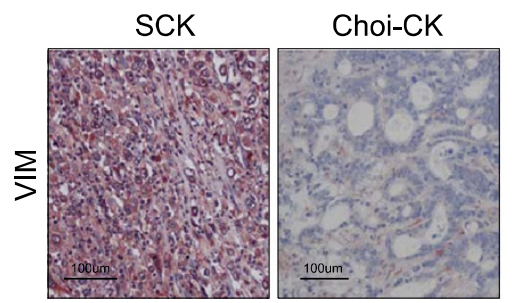

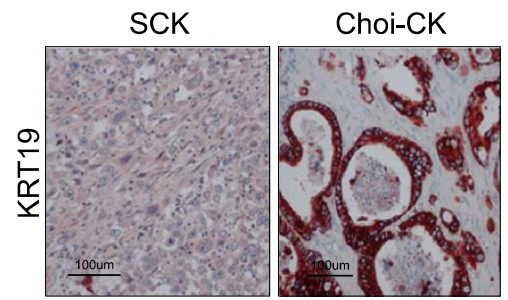

Figure 1. The morphological and immunohistochemical characteristics of the $4 \mathrm{CC}$ cell lines. (A) Phase contrast images of the $4 \mathrm{CC}$ cell lines that were monolayer-cultured in DMEM supplemented with $10 \% \mathrm{FBS}$ and $1 \%$ antibiotics-antimycotics in a $5 \% \mathrm{CO}_{2}$-air conditioned $37^{\circ} \mathrm{C}$ incubator. (B) Histochemical findings of the xenotransplanted tumors derived from the 4 CC cell lines (SCK, JCK1, Cho-CK or Choi-CK). The anaplastic spindle cells with a fascicular arrangement in a xenotransplanted tumor derived from SCK cells. The poorly differentiated adenocarcinoma derived from the JCK1 cells. The moderately differentiated and the well differentiated adenocarcinomas derived from the Cho-CK and Choi-CK cells, respectively (H\&E, $\times 100$; upper panels). Immunohistochemistry (IHC) with an anti-KRT7 antibody stained for the xenotransplanted tumors derived from the $4 \mathrm{CC}$ cell lines. SCK cell-derived tumor; most of the spindle cells were barely stained. IHC with anti-KRT7 antibody in the xenotransplanted tumor tissues, according to the tumor differentiation (lower panels). (C) Immunohistochemical staining of the original tumor tissues. Vimentin and KRT19 expressions were examined in the sarcomatoid (SCK) and the differentiated (Choi-CK) CC tissues, respectively. 
suppressor genes, including the $p 53$ gene and the fragile histidine triad (FHIT) gene, and the expression of a well-known CC-related receptor and its ligand Fas/Fas-ligand (FasL) in the sarcomatous $\mathrm{CC}$ cell line as well as in other carcinomatous CC cell lines. In addition, we used cDNA microarrays to investigate the genes that are associated with EMT in CC. We found up- or down-regulated genes in the sarcomatous SCK cells, as compared with the differentiated Choi-CK cells. The genes identified or characterized through this approach are potential candidates for those genes involved in the cancer metastasis and invasiveness of CC.

\section{Results}

\section{The histology and immunohistochemistry of the xenoplanted tumors}

The SCK, JCK and Cho-CK cells were originally derived from a peripheral type of intrahepatic CC. The Choi-CK cells were cultured from a hilar type of infiltrative CC. The SCK cells showed the spindle- shaped (fibroblastoid) morphology and loose cell- cell adhesion. In contrast, the Cho-CK and Choi- CK cells showed the polygonal and epitheloid morphology, and tight cell-cell adhesion. The JCK1 cells showed the intermediate type of morphology between the SCK and Cho-CK cells (Figure 1A). All four CC lines were tumorigenic in nude mice. Following subcutaneous injection of tumor-cell suspensions into the nude mice, the resulting tumors reached diameters of $1 \mathrm{~cm}$ within 3 months. The histology of the tumors growing in the nude mice was similar to that of the original tumors. The xenoplanted SCK cell tumors were mainly composed of anaplastic spindle cells with a fascicular arrangement, and these findings were compatible with the characteristics of sarcomatoid adenocarcinoma. The xenotransplanted JCK1 cell tumors were poorly differentiated adenocarcinomas that consisted of nested large anaplastic cells with sparse glandular differentiation. The xenotransplanted Choi-CK or Cho-CK cell tumors revealed well- and moderately-differentiated adenocarcinomas, respectively, and these formed glandular structures (Figure 1B). A summary of the immunohistochemical results is shown in Table 1 . The tumors originating from the JCK1, Cho-CK or Choi-CK cells showed positive reactions for KRT7 and for KRT19, which are well-known markers of bile duct cells, and they were also positive for EMA. The sarcomatoid carcinoma SCK cell tumors were barely positive for KRT7/19, they were strongly positive for vimentin and they had a luminal staining pattern for CEA at a few abortive
Table 1. The expression patterns of marker proteins by immunohistochemical staining.

\begin{tabular}{lcccc}
\hline \multicolumn{1}{c}{ Antigen } & SCK & JCK1 & Cho-CK & Choi-CK \\
\hline KRT7 & - & $+/-$ & + & ++ \\
KRT19 & $+/-$ & + & + & $+/-$ \\
KRT20 & - & - & - & - \\
CEA & $+/-$ & $+/-$ & + & ++ \\
EMA & $-(+)^{*}$ & + & + & + \\
VIM & ++ & - & - & - \\
AFP & - & - & - & - \\
Albumin & - & - & - & - \\
Fibrinogen & - & - & - & - \\
\hline
\end{tabular}

,$->95 \%$ of the cells could not be determined as positive; +- , the cells are focally positive between $5 \%$ and $24 \%$; + , the percentage of cells determined as positive is from $25 \%$ up to $75 \%$; ++, $>75 \%$ of the cells are positive with clearly distinguishable strength. ${ }^{*}$ The immunoreactivity for KRT7 or EMA was positive in the primary tumors, but it was negative in the xenotransplanted tumors (KRT, keratin; CEA, carcinoembryonic antigen; EMA, epithelial membrane antigen; VIM, vimentin; AFP, alpha-fetoprotein).

glandular luminal borders. Immunoreactivity for EMA was positive in the primary SCK tumors, but this was negative in the xenoplanted tumors from the SCK cells. All the other markers of hepatocellular carcinoma that were tested were negative for all 4 types of tumors.

\section{p53 mutations}

We examined the p53 protein expression by immunoblot analysis in the four $\mathrm{CC}$ cell lines and we found that the Cho-CK and Choi-CK cells strongly expressed p53 protein, but the SCK and JCK1 cells weakly expressed p53 protein (Figure $2 \mathrm{~A})$. Particularly, the size of the p53 protein expression of the JCK1 cells was smaller than that of other CC cells on PAGE electrophoresis. The p21, which is downstream from the p53, was detected in the Choi-CK cells, but p21 was weakly expressed in the SCK and Cho-CK cells. The JCK1 cells did not show a p21 expression. To determine the p53 function, we treated the cells with the p53-inducing agent doxorubicin (Dox, 0.2 $\mu \mathrm{g} / \mathrm{ml}$ ). Dox efficiently induced a p53 expression in the SCK, Cho-CK, and Choi CK cells in a time dependent manner, but it did not in the JCK1 cells. Induction of the p53 expression was accompanied by the downstream p21 expression. These results suggested that the SCK, Cho-CK, and Choi-CK cells have the functional p53, but the JCK1 cells have nonfunctional p53. Next we checked the $p 53$ mutation by genomic DNA sequencing and the cDNA sequencing method (Table 2). SCK showed a deletion mutation of 24 bp of codon 262 to 269 
A
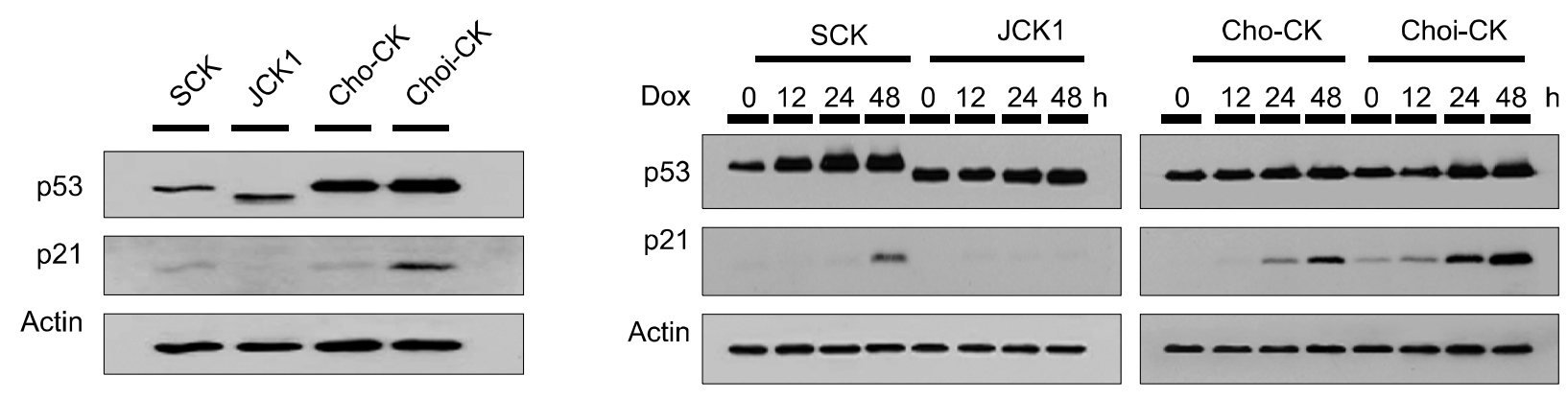

B

\section{5 ' - CAGTGGTAATCTACTGGGACGGAA-3'}
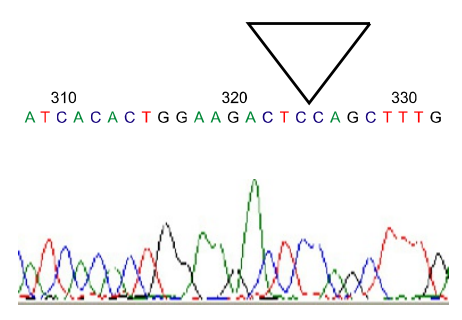

C

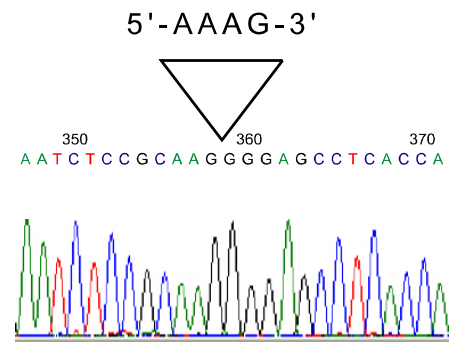

D

MEEPQSDPSVER PLSQETFS DLW KLLPENNVIS PLPSQAMDDLMUS P DDI EQW FTEDPGP DEAP RMP EAA PRVAPAPAAPTPAAPAPAPSWRLSSSVPSQKTYQGSYGFRUGFLHSGTAKSVTCTYSPATNRMFCQLAKT CPVQLWVDSTP P PGTRVAMAIYKQSQHMTEVVRRCP HHERCSDSDGLAP PQHLIRVEGNLRVEYLDDRN TFRH SVVVPYEP PEVGS DCTTI HYNYMCNSS CMGGMNRRP ILTIITLEDSSGNLIGRNS FEVRVCACPGR DRRTEEENLRKGSLTTSCPOGALSEHCPTTPAPLPSORRNHWMENISPFRSVGVSASRCSES (STOP)

Figure 2. The functional status and the mutation analyses of the p53 in the $4 \mathrm{CC}$ cell lines. (A) The p53 expression was analyzed by Western blot analysis. Thirty $\mu \mathrm{g}$ of extracted proteins were resolved by $12 \%$ SDS-PAGE and then they were transferred to the membrane. The blots were probed with anti-p53 (DO-1) or anti-p21 (C-19) antibody, and then they were stripped and reprobed with a monoclonal antibody to actin as a loading control. To activate the p53 gene expression, the cells were treated with $0.2 \mu \mathrm{g} / \mathrm{ml}$ doxorubicin (Dox) for the indicated time intervals. Thirty $\mu \mathrm{g}$ of the cell lysates were processed for Western blot analysis (right two panels). (B) The sequencing profiles show a deletion of 24 bp in codon 262-269 (nt 977-1000, NM_000546.4) spanning exon 7 and exon 8 without a frame shift in the p53 gene of the SCK cells. (C) A deletion of 4 bp in codon 292-293 of exon 8 (nt 1071-1074, NM_000546.4) with a frame shift in the p53 gene of the JCK cells. (D) The premature termination and altered N-terminal amino acids (bold and underlined) by the frame shift in the $p 53$ gene of the JCK cells.

Table 2. Somatic mutation of p53 in the human intrahepatic cholangiocarcinoma cell lines.

\begin{tabular}{|c|c|c|c|c|c|}
\hline Cell line & Polymorphism & Point mutation & Frame shift & Deletion & $\begin{array}{l}\text { Premature } \\
\text { termination }\end{array}$ \\
\hline SCK & $\begin{array}{l}\text { CCC }(\text { Pro })>\text { CGC }(\text { Arg) } \\
\text { codon } 72 \text { of exon } 4\end{array}$ & - & - & $\begin{array}{l}24 \text { bp; codon } 262 \\
-269 \text { of exon } 8\end{array}$ & - \\
\hline JCK1 & - & - & + & $\begin{array}{c}4 \mathrm{bp} \text {; codon } 292 \\
-293 \text { of exon } 8\end{array}$ & + \\
\hline Cho-CK & - & $\begin{array}{l}\text { GTG }(\text { Val })>\text { GCG (Ala) } \\
\text { Codon } 143 \text { of exon } 5\end{array}$ & - & - & - \\
\hline Choi-CK & - & $\begin{array}{l}\text { ATG (Met) }>\text { GTG }(\text { Val); } \\
\text { codon } 169 \text { of exon } 5 \\
\text { CGT }(\text { Arg) }>\text { TGT (Cys) } \\
\text { Condon } 273 \text { of exon } 8\end{array}$ & - & - & - \\
\hline
\end{tabular}


(NM_000546.4) without a frame shift. In contrast, the JCK1 cells showed a deletion mutation of $4 \mathrm{bp}$ in codon 292 to 293 with a frame shift and premature termination (Figure $2 \mathrm{~B}$ and $\mathrm{C}$ ). The JCK1 cells also revealed the mutant $p 53$ that consisted of 342 amino acids, which is smaller than the wild-type $p 53$ that consisted of 393 amino acids (Figure 2D). In addition, Cho-CK cells showed a point mutations in codon 143, while Choi-CK cells revealed two point mutations in codon 169 and 273 of $p 53$, respectively.

\section{The expressions of the FHIT gene and Fas/FasL mRNA}

All four CC cell lines expressed the FHIT gene transcripts. A PCR product of 707 bp (using primers $5 \mathrm{U} 1$ and 3D1), which corresponded to the expected size of the FHIT RT-PCR product (Ohta et al., 1996), was observed in the JCK1 and Cho-CK cells. However, the SCK cells displayed normal and aberrant FHIT gene transcripts, implying that the normal and abnormal alleles function together. The Choi-CK cells showed an aberrant FHIT transcript (Figure 3A). The second set of primers (MUR5 and RP2) amplifies a fragment of FHIT CDNA that is identical to, but 40 bp longer, than the fragment generated by $5 \mathrm{U} 1$ and 3D1. Next, we determined whether the altered expression of the apoptosis-related genes such as Fas/FasL is associated with the tumor progression of CC. RT-PCR analysis revealed that all $4 \mathrm{CC}$ cell lines expressed Fas and FasL, although their expression levels varied among the different cell lines. The SCK cells had lower expression levels of
Fas/FasL mRNA, which was consistent with the previous report (Shimonishi et al., 2000). In contrast, the JCK1, Choi-CK and Cho-CK cells revealed higher expression levels of Fas/FasL mRNA (Figure 3B).

\section{The differential expression of mRNAs in the sarcomatoid CC cells}

To identify the distinct genes related to sarcomatous events, we performed gene expression profiling with using cDNA microarrays. The gene expression changes were mainly monitored using the high density microarrays with 14,080 (14k) cDNAs. Three separate mRNA isolations were obtained from each cell line and pair-wise hybridizations were then performed three times. Three independent hybridizations were repeated for the dye-swap experiments. The hybridizations were scanned and quantitative information was obtained for each hybridization. In order to search for the genes with significant differences in expression between the sarcomatous CC and the well differentiated CC cells, we performed the SAM oneclass test (Figure 4A and B). Starting with their expression values from the $14 \mathrm{k}$ dataset $(14,077$ genes), this approach resulted in a list of 456 clones (244 up-regulated and 212 down-regulated), using a significance threshold that was expected to produce fewer than 10 false positives. A similar procedure was applied to the $4.6 \mathrm{k}$ dataset $(4,414$ genes) with fewer than 3 expected false positives. Additional 51 clones (16 up-regulated and 35 down-regulated) were selected. From these lists, we report in Table 3 only on those genes that were
A

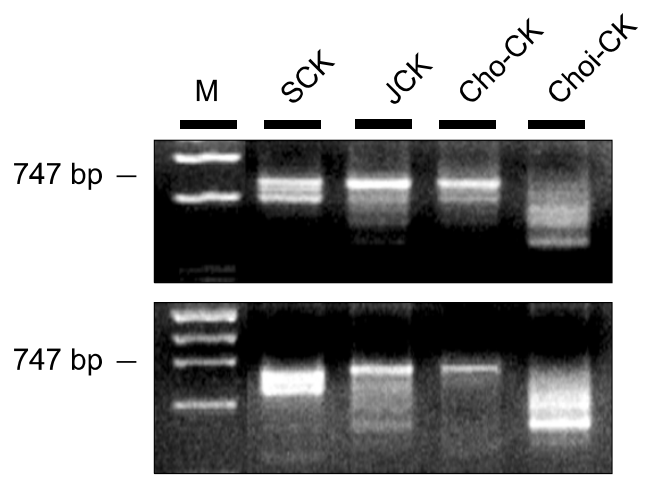

B

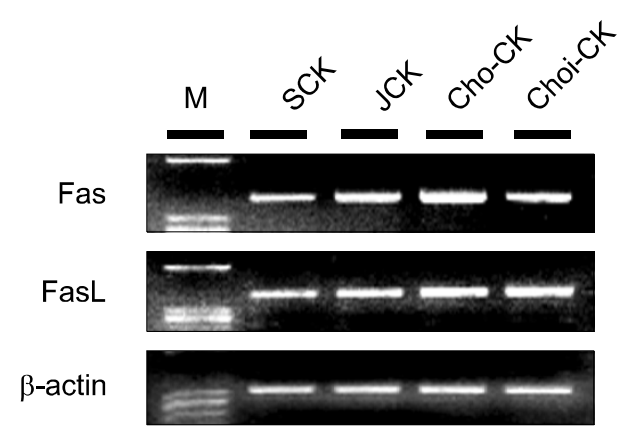

Figure 3. Genetic alterations of FHIT and Fas/FasL in the CC cells. (A) RT-PCR analysis of the FHIT gene product in the 4 CC cell lines with using nested PCR. The total RNA isolated from the cells was subjected to RT-PCR. Inner primers 5 U1 and 3D1 were used (upper). Inner primers MUR5 and RP2 were used (lower). The PCR products were separated on $2 \%$ agarose gels. Arrow, the 707 bp or 747 bp FHIT gene product. Lane M, molecular weight markers. (B) Semiquantitative PCR analysis of the Fas/FasL mRNA expression. The total RNA was extracted from the CC cell lines. The Fas/FasL mRNA expression was analyzed by reverse-transcriptase PCR with using primers for Fas/FasL and for $\beta$-actin as an internal control, as described in the Methods section. 
A

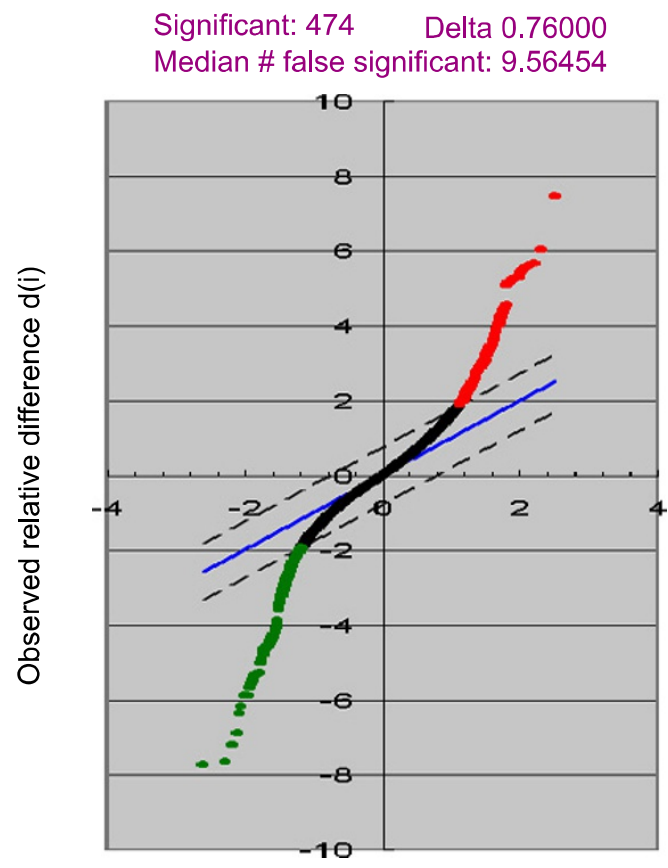

Expected relative difference $d_{E}(i)$
B

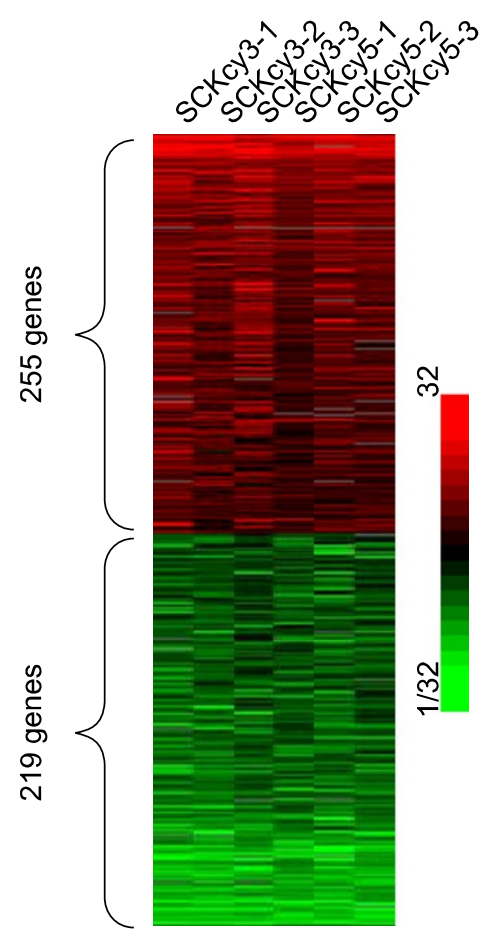

C
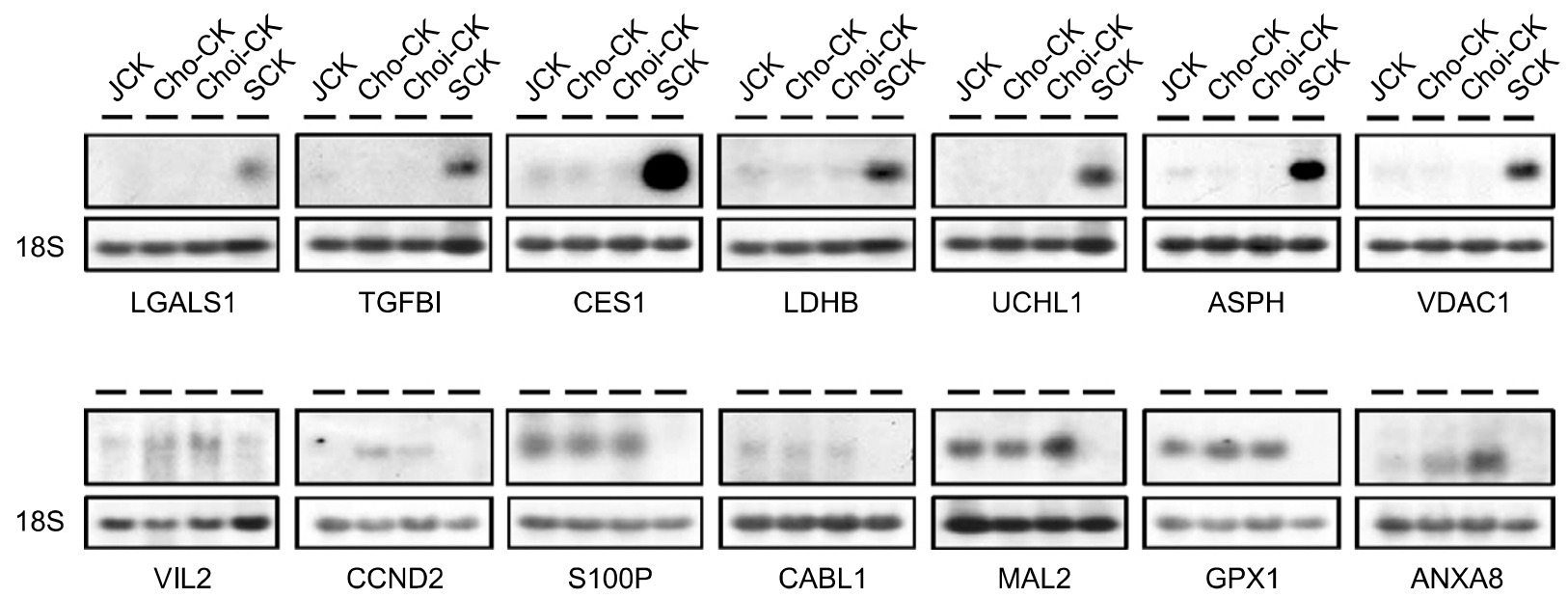

Figure 4. Pair wise analysis by a modified $t$-test of SAM and the validation of the CDNA microarray data. (A) The scatter plot of the observed relative difference $(d i)$ versus the expected relative difference $d_{E}(\lambda)$. The solid line indicates the line for $d(i)=d_{E}(j)$, where the observed relative difference is identical to the expected relative difference. The dashed lines are drawn at a distance $\Delta=0.758$ from the solid line. The 474 potentially significant genes for $\Delta=$ 0.758 are indicated by red circles ( 255 up-regulated genes) and green circles (219 down-regulated genes) from the 14k dataset (14,077 genes). (B) The raw expression values $\left(\log _{2}\right)$ of the 474 differentially expressed genes for the SCK cells, as compared to the control for the Choi-CK cells, are shown rank-ordered according to the fold change score. The triplicate expression ratios (the Cy5/Cy3 ratio) between the experimental samples (SCKCy5-1, -2 , and -3 ) and the reference (Choi-CKCy3-1, -2, and -3) were repeated after swapping dye (SCKCy3-1, -2, and -3 versus Choi-CKCy5-1, -2, and -1). (C) Northern blot analysis of the LGALS1, TGFBI, CES1, LDHB, UCHL1, ASPH, VDAC1, VIL2, CCND2, S100P, CALB1, MAL2, GPX1 and ANXA8 gene expressions for the validation of the CDNA microarray data. The total RNA extracts from the JCK, Cho-CK, Choi-CK and SCK cells were fractionated by electrophoresis on $1 \%$ agarose gels that contained formaldehyde, and the proteins were then transferred to membranes. The blots were hybridized overnight with $2 \times 10^{6} \mathrm{cpm} / \mathrm{ml}$ of each CDNA probe labeled with [ $\left.{ }^{32}\right] \mathrm{dCTP}$ (NEN) by randompriming; they were then washed and next exposed to X-Omat AR film (Kodak) at $-70^{\circ} \mathrm{C}$. The blot was stripped and subsequently rehybridized with a probe for $18 \mathrm{~S}$ cDNA as a loading control (lower). 
Table 3. The genes that are differentially expressed between the sarcomatoid (SCK) and the differentiated (Choi-CK) CC cells.

A. The differentially up-regulated genes in the sarcomatoid CC cells.

\begin{tabular}{|c|c|c|c|c|c|}
\hline Function & Unigene ID & Unigene No & Annotation & Symbol & Fold change \\
\hline \multirow[t]{7}{*}{ Cell adhesion } & 240388 & Hs.445351 & Galectin-1 & LGALS1 & 10.3 \\
\hline & 131112 & Hs.1908 & Serglycin & SRGN & 5.2 \\
\hline & 143717 & Hs.106880 & Bystin-like & $B Y S L$ & 4.8 \\
\hline & 131973 & Hs.6838 & Rho family GTPase 3 & RND3 & 4.7 \\
\hline & 2481209 & Hs.650585 & Laminin, beta 1 & LAMB1 & 4.2 \\
\hline & 139586 & Hs.73793 & Vascular endothelial growth factor $\mathrm{A}$ & VEGFA & 4.2 \\
\hline & 1205348 & Hs.531081 & $\begin{array}{l}\text { Lectin, galactoside-binding, } \\
\text { soluble, } 3 \text { (galectin 3) }\end{array}$ & LGALS3 & 4.1 \\
\hline Cytoskeletal structure & 2224039 & Hs.642813 & Vimentin & VIM & 14.8 \\
\hline \multirow[t]{3}{*}{ Growth regulation } & 619193 & Hs.450230 & $\begin{array}{l}\text { Insulin-like growth factor-binding } \\
\text { protein-3 gene }\end{array}$ & IGFBP3 & 7.4 \\
\hline & 158415 & Hs.173894 & $\begin{array}{l}\text { Macrophage-specific colony-stimulating } \\
\text { factor }\end{array}$ & CSF-1 & 6.6 \\
\hline & 198057 & Hs.118787 & $\begin{array}{l}\text { Transforming growth factor, } \\
\text { beta-induced, } 68 \mathrm{kD}\end{array}$ & TGFBI & 5.8 \\
\hline \multirow[t]{3}{*}{ Metabolism } & 1841001 & Hs.558865 & Carboxylesterase 1 & CES1 & 10.6 \\
\hline & 241186 & Hs.446 & Lactate dehydrogenase B & $L D H B$ & 5.1 \\
\hline & 172529 & Hs.268849 & Glyoxalase I & GLO1 & 4.1 \\
\hline \multirow{3}{*}{ Transcription } & 140374 & Hs.79353 & Transcription factor Dp-1 & TFDP1 & 5.9 \\
\hline & 1953698 & Hs.584909 & SCAN domain-containing 1 & SCAND1 & 4.9 \\
\hline & 150816 & Hs. 14453 & Interferon regulatory factor 8 & IRF8 & 4.4 \\
\hline \multirow[t]{2}{*}{ Protein processing } & 909478 & Hs.518731 & Ubiquitin carboxyl-terminal esterase L1 & UCHL1 & 23.2 \\
\hline & 3525600 & Hs.714780 & Transducer of ERBB2, 1 & TOB1 & 5.8 \\
\hline \multirow[t]{15}{*}{ Miscellaneous } & 703399 & Hs.488240 & Uridine phosphorylase & $U P$ & 12.4 \\
\hline & 092009 & Hs.622998 & $\begin{array}{l}\text { Aspartate beta-hydroxylase, } \\
\text { transcript variant } 3\end{array}$ & $A S P H$ & 11 \\
\hline & 136757 & Hs.40499 & Dickkopf (Xenopus laevis) homolog 1 & $D K K 1$ & 10.7 \\
\hline & 136499 & Hs.37107 & Melanoma antigen, family $\mathrm{A}, 4$ & MAGEA4 & 8.5 \\
\hline & 162861 & Hs.203206 & Exportin 5 mRNA & XPO5 & 6.2 \\
\hline & 136473 & Hs.6120 & Zinc finger, AN1-type domain 3 & ZFAND3 & 5.7 \\
\hline & 3525587 & Hs.714767 & Golgi reassembly stacking protein 1 & GORASP1 & 5.3 \\
\hline & 2065460 & Hs.596449 & $\begin{array}{l}\text { Serpin peptidase inhibitor, clade } \mathrm{H} \\
\text { (heat shock protein } 47 \text { ), member } 1\end{array}$ & SERPINH1 & 4.8 \\
\hline & 716538 & Hs.501379 & $\begin{array}{l}\text { DEAD/H (Asp-Glu-Ala-Asp/His) } \\
\text { box polypeptide } 32\end{array}$ & DHX32 & 4.7 \\
\hline & 1086100 & Hs.525899 & Prickle homolog 4 (Drosophila) & PRICKLE4 & 4.7 \\
\hline & 231694 & Hs. 436657 & Clusterin & $C L U$ & 4.6 \\
\hline & 2976618 & Hs.696013 & H2A histone family, member $Y$ & $H 2 A F Y$ & 4.5 \\
\hline & 154270 & Hs.153952 & 5 ' nucleotidase (CD73) & NT5 & 4.3 \\
\hline & 183662 & Hs.311190 & Mitochondrial ribosomal protein L14 & MRPL14 & 4.2 \\
\hline & 910067 & Hs.519320 & Voltage-dependent anion channel 1 & VDAC1 & 4.2 \\
\hline \multirow[t]{8}{*}{ Unknown } & 715671 & Hs.500 & ycomb group ring finger 5 & PCGF5 & 8.4 \\
\hline & 137156 & Hs.44098 & Hypothetical gene supported by BX647608 & LOC399959 & 8.1 \\
\hline & 3525613 & Hs.714793 & ESTs & & 7.9 \\
\hline & 2092009 & Hs.622998 & ESTs & & 7.2 \\
\hline & 135738 & Hs.30026 & cDNA FLJ77664 complete cds & FLJ77664 & 6.5 \\
\hline & 198869 & Hs.370781 & $\begin{array}{l}\text { Pyridoxal-dependent decarboxylase } \\
\text { domain containing } 1\end{array}$ & $P D X D C 1$ & 4.9 \\
\hline & 13090 & Hs.1048 & KIT ligand & KITLG & 4.79 \\
\hline & 1782987 & Hs.567498 & Chromosome 4 open reading frame 18 & C4orf18 & 4.6 \\
\hline
\end{tabular}

The genes up-regulated by more than 4-fold were selected by SAM analysis with an FDR up to 0.02 . Unigene ID and Unigene No were based on the database of UniGene Build \#215. 
B. The differentially down-regulated genes in the sarcomatoid CC cells.

\begin{tabular}{|c|c|c|c|c|c|}
\hline Function & Unigene ID & Unigene No & Annotation & Symbol & Fold change \\
\hline \multirow[t]{11}{*}{ Cytoskeletal structure } & 219875 & Hs.406013 & Keratin 18 & KRT18 & -10.6 \\
\hline & 170416 & Hs.253903 & Stomatin & STOM & -9.1 \\
\hline & 709078 & Hs.493919 & Myelin protien zero-like 1 & MPZL1 & -9.1 \\
\hline & 221823 & Hs.411501 & Keratin 7 & $K R T 7$ & -6.3 \\
\hline & 2723698 & Hs.654380 & $\begin{array}{l}\text { Keratin } 14 \text { (epidermolysis bullosa } \\
\text { simplex, Dowling-Meara, Koebner) }\end{array}$ & KRT14 & -6 \\
\hline & 157619 & Hs.170473 & Pleckstrin 2 (mouse) homolog & PLEK2 & -5.5 \\
\hline & 1293157 & Hs.533782 & Keratin 8 & KRT8 & -5.4 \\
\hline & 2723888 & Hs.654570 & Keratin 15 & KRT15 & -5.3 \\
\hline & 2723886 & Hs.654568 & Keratin 19 & KRT19 & -5.1 \\
\hline & 909782 & Hs.519035 & Ladinin 1 & $L A D 1$ & -4.5 \\
\hline & 702186 & Hs.487027 & Villin 2 (ezrin) & VIL2 & -4 \\
\hline \multirow[t]{4}{*}{ Cell growth } & 703452 & Hs.488293 & $\begin{array}{l}\text { Epidermal growth factor receptor } \\
\text { (avian erythroblastic leukemia viral } \\
\text { (v-erb-b) oncogene homolog) }\end{array}$ & $E G F R$ & -10.9 \\
\hline & 145212 & Hs.118110 & Bone marrow stromal cell antigen 2 & BST2 & -9.2 \\
\hline & 201376 & Hs.376071 & Cyclin D2 & CCND2 & -7.3 \\
\hline & 173112 & Hs.270833 & $\begin{array}{l}\text { Amphiregulin (schwannoma-derived } \\
\text { growth factor) }\end{array}$ & $A R E G$ & -6.2 \\
\hline \multirow[t]{4}{*}{ Cell signaling } & 907411 & Hs.516664 & Ephrin-A1 & EFNA1 & -9 \\
\hline & 172401 & Hs.268177 & $\begin{array}{l}\text { Phospholipase C, gamma } 1 \\
\text { (formerly subtype 148) }\end{array}$ & PLCG1 & -4.5 \\
\hline & 14403 & Hs.110642 & EST & & -4.1 \\
\hline & 627377 & Hs.458414 & $\begin{array}{l}\text { Interferon induced transmembrane } \\
\text { protein } 1(9-27)\end{array}$ & IFITM1 & -4 \\
\hline \multirow[t]{4}{*}{ Transcription } & 146283 & Hs.122523 & $\begin{array}{l}\text { Staphylococcal nuclease and tudor } \\
\text { domain containing } 1\end{array}$ & SND1 & -12 \\
\hline & 2724606 & Hs.655288 & Male-specific lethal-3 (Drosophila)-like 1 & MSL3L1 & -5.3 \\
\hline & 13102 & Hs.1545 & Caudal type homeo box transcription factor 1 & $C D \times 1$ & -4.7 \\
\hline & 716182 & Hs.501023 & MAX-interacting protein 1 & $M X I 1$ & -4.3 \\
\hline \multirow[t]{2}{*}{ Calcium binding } & 131328 & Hs.2962 & S100 calcium-binding protein $\mathrm{P}$ & S100P & -17.1 \\
\hline & 139098 & Hs.65425 & Calbindin 1, (28 kD) (CALB1) & $C A L B 1$ & -4.1 \\
\hline \multirow[t]{2}{*}{ Protein biosynthesis } & 1955212 & Hs.586423 & $\begin{array}{l}\text { Eukaryotic translation elongation } \\
\text { factor } 1 \text {, alpha } 1\end{array}$ & EEF1A1 & -9.4 \\
\hline & 219562 & Hs.405590 & $\begin{array}{l}\text { Eukaryotic translation initiation } \\
\text { factor } 3 \text {, subunit } 6(48 \mathrm{kD})\end{array}$ & EIF3S6 & -5.5 \\
\hline \multirow{3}{*}{$\begin{array}{l}\text { Major histocompability } \\
\text { antigen }\end{array}$} & 2723722 & Hs.654404 & Major histocompatibility complex, class I, C & $H L A-C$ & -8.2 \\
\hline & 140173 & Hs.77961 & Major histocompatibility complex, class I, B & $H L A-B$ & -8 \\
\hline & 910719 & Hs.519972 & Major histocompatibility complex, class I, F & $H L A-F$ & -7 \\
\hline \multirow[t]{14}{*}{ Miscellaneous } & 2723831 & Hs. 58247 & Protease, serine, 3 & PRSS3 & -22.2 \\
\hline & 198836 & Hs.370725 & Oxysterol binding protein-like $1 \mathrm{~A}$ & OSBPL1A & -15.4 \\
\hline & 133582 & Hs.16426 & Podocalyxin-like & PODXL & -11.1 \\
\hline & 162274 & Hs.76550 & Mal, T-cell differentiation protein 2 & MAL2 & -10.4 \\
\hline & 131280 & Hs.2704 & Glutathione peroxidase 2 (gastrointestinal) & GPX2 & -9.5 \\
\hline & 139672 & Hs.74471 & $\begin{array}{l}\text { Homo sapiens gap junction protein, } \\
\text { alpha } 1,43 \mathrm{kD} \text { (connexin } 43)\end{array}$ & GJA1 & -7.3 \\
\hline & 3369927 & Hs.714347 & Vestigial like 3 (Drosophila) & VGLL3 & -6.7 \\
\hline & 142859 & Hs.100686 & Anterior gradient homolog 3 (Xenopus laevis) & AGR3 & -6.6 \\
\hline & 915027 & Hs.524280 & $\mathrm{H} 2 \mathrm{~A}$ histone family, member $\mathrm{J}$ & H2AFJ & -5.6 \\
\hline & 3321528 & Hs.709321 & $\begin{array}{l}\text { Interferon induced transmembrane } \\
\text { protein } 2(1-8 D)\end{array}$ & IFITM2 & -5.5 \\
\hline & 220890 & Hs.407995 & Macrophage migration inhibitory factor & MIF & -5.1 \\
\hline & 1281472 & Hs.532634 & Interferon, alpha-inducible protein 27 & IFI27 & -4.7 \\
\hline & 132000 & Hs.6980 & Aldo-keto reductase family 7 , member $\mathrm{A} 3$ & A AKR7A3 & -4.5 \\
\hline & 154247 & Hs.153768 & $\begin{array}{l}\text { Ribosomal RNA processing 9, small } \\
\text { subunit (SSU) processome } \\
\text { component, homolog (yeast) }\end{array}$ & $R R P 9$ & -4.3 \\
\hline
\end{tabular}


B. Continued.

\begin{tabular}{|c|c|c|c|c|c|}
\hline Function & Unigene ID & Unigene No & Annotation & Symbol & Fold change \\
\hline & 239804 & Hs.444767 & Kinesin family member $13 \mathrm{~B}$ & KIF13B & -4.2 \\
\hline & 907713 & Hs.516966 & BCL2-like 1 & $B C L 2 L 1$ & -4.2 \\
\hline & 1371620 & Hs.535306 & Annexin A8 & ANXA8 & -4.1 \\
\hline \multirow[t]{8}{*}{ Unknown } & 1371620 & Hs.535306 & Hypothetical protein FLJ20171 & FLJ20171 & -9.3 \\
\hline & 132620 & Hs.10095 & Similar to hCG2004878 & LOC729433 & -8.5 \\
\hline & 156459 & Hs. 162757 & Low density lipoprotein-related protein 1 & $L R P 1$ & -5.5 \\
\hline & 169386 & Hs.177425 & $\begin{array}{l}\text { Discs, large (Drosophila) homolog-associated } \\
\text { protein } 4\end{array}$ & DLGAP4 & -5.4 \\
\hline & 2728719 & Hs. 659401 & cDNA FLJ34018 fis, clone FCBBF2002801 & & -5.2 \\
\hline & 677500 & Hs.462341 & Myosin phosphatase Rho interacting protein & MPRIP & -5 \\
\hline & 132883 & Hs.12319 & $\begin{array}{l}\text { Amyotrophic lateral sclerosis } 2 \text { (juvenile) } \\
\text { chromosome region, candidate } 4\end{array}$ & ALS2CR4 & -4.5 \\
\hline & 702630 & Hs.487471 & RNA binding motif protein $35 \mathrm{~A}$ & $R B M 35 A$ & -4.5 \\
\hline
\end{tabular}

The genes down-regulated by more than 4-fold were selected by SAM analysis with an FDR up to 0.02 . Unigene ID and Unigene No were based on the database of UniGene Build \#215.

up- or down-regulated by more than 4-fold. The expression of 42 genes was enhanced at least 4-fold in the SCK cells, while that of 55 genes was reduced by 4 -fold or more. The expression of vimentin showed the highest fold induction (24.7-fold). We also observed the up-regulation of genes that encode adhesion molecules, including $L G A L 1, P R G 1$, $B Y S L, A R H E, L A M B 1, V E G F$ and LGAL3. Genes associated with cell growth regulation (IGFBP3, CSF-1 and TGFBI) were also over- expressed in the SCK cells. In contrast, the expression of the PRSS4 gene showed the largest decrease in expression (-22.2-fold). The down- regulated cytoskeletal structure genes included KRT18, EPB72, MPZL1, KRT7, KRT14, PLEK2, KRT8, KRT15, KRT19, LAD1 and VIL2 in the sarcomatous CC cells.

\section{Verification of the cDNA microarray data}

The preferential expression of VIM or CK7/19 in the SCK or Choi-CK cells, respectively, was confirmed by immunohistochemical staining, as is shown in Figure 1. Thus, to further validate the cDNA microarray data, 14 genes were randomly selected and these were examined by Northern blotting (Figure 4C). The LGALS1, TGFBI, CES1, $\angle D H B, U C H L 1, A S P H$ and VDAC1 mRNAs were preferentially expressed in the SCK cells in accordance with the microarray results. The VIL2, CCND2, S100P, CALB1, MAL2, GPX2 and ANXA8 mRNAs were over-expressed in the carcinomatous CC cell lines, whereas their expressions were not detectable, or they were weak, in the sarcomatoid SCK cells, which was also consistent with the microarray data. Interestingly, the expression of VIL2 and ANXA8 mRNA decreased according to the degree of abnormal differentiation. Next, we immu- nohistochemically validated the expressions of four genes, $L D H B$, UCHL1, S100P, and GPX1 in CC tissues with well, moderate, poor, or sarcomatous differentiation, respectively (Figure 5). The immunoreactivities of LDHB and UCHL1 were increased according to the degree of abnormal tumor differentiation. In contrast, the immunoreactivities of S100P and GPX1 were decreased according to the degree of abnormal tumor differentiation. These findings were consistent with the microarray data.

\section{Discussion}

The KRT profile of normal cells, from which tumor stem cells are generally retained during neoplastic transformation, can be used for differentiating hepatocellular carcinoma from CC (Wu et al., 1996). Thus, KRTs are a widely recognized tool for the phenotypic identification of hepatocytes (these are positive for KRT8 and KRT18) and bile-duct cells (these are positive for KRT7, KRT8, KRT18 and KRT19). However, this distinction is not applicable to all primary liver tumors and especially to mixed neoplasms, where the morphology and expression of different KRTs frequently overlap (Goodman et al., 1985). The combination of morphology and the expression of KRTs and albumin can reliably differentiate the majority of hepatocellular carcinomas and CC (D'Errico et al., 1996). Our data provide evidence that SCK cells are sarcomatous CC cells. Fortunately, the other 3 CC cell lines (JCK1, Cho-CK and Choi-CK cells) show different histological grades of differentiation, e.g., they are poorly, moderately and well differentiated phenotypes, respectively. Thus, we suggest that these cells are excellent models to investigate the 

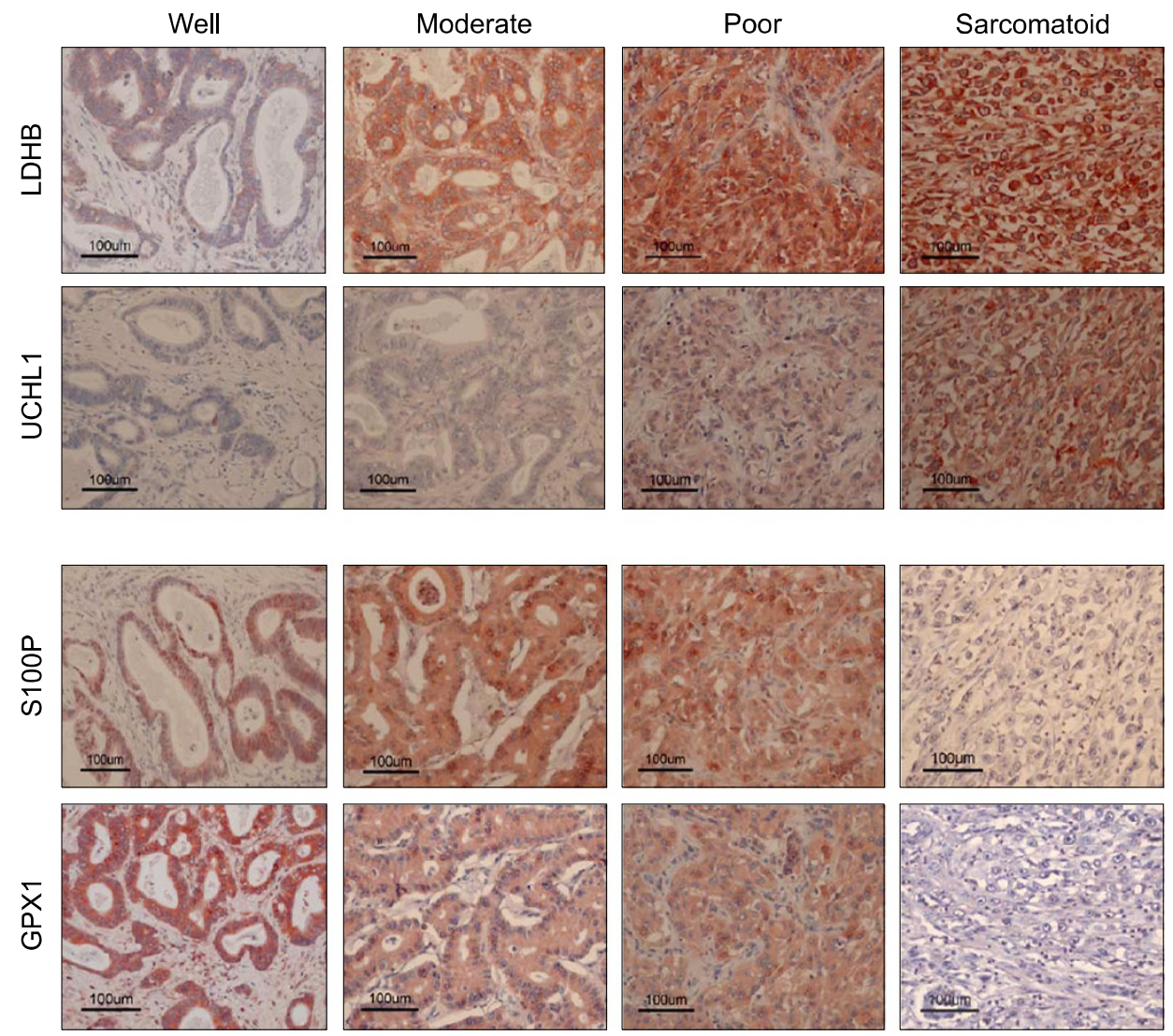

Figure 5. Immunohistochemical examination of the gene expressions in CC tissues with well, moderate, poor, or sarcomatous differentiation, respectively. The expressions of LDHB (A) and UCHL1 (B), S100P (C), and GPX1 (D) were increased or decreased according to the degree of abnormal tumor differentiation.

progression of CC.

The $p 53$ gene is one of the most frequently mutated genes in all types of cancers. Most p53 mutations occur in exons 5-8 (Levine, 1992). However, mutations also occur at other sites as well. We extended the examination of the p53 gene from exons 1 to 10 . The deletion mutation of the p53 gene may be involved in the sarcomatous change or the tumor progression of CC cells. The FHIT gene was recently described as another candidate tumor suppressor gene that has been implicated in the development of various epithelial cancers, including esophageal, gastric, lung, head, neck and Merkel cell cancers (Sozzi et al., 1996). About $50 \%$ of these tumors display aberrant FHIT gene transcripts, which lack exons that are considered relevant for the normal function of that encoded protein. While the Choi-CK cells displayed an aberrantly migrating FHIT transcript, the SCK cells showed the both the aberrant and normal transcripts. Therefore, this aberrant FHIT transcript does not seem to be relevant to the histological degree of differentiation. A tumor evasion mechanism involving Fas/FasL exists in intrahepatic cholangiocarcinoma and the downregulation of Fas and FasL was correlated with histo- logic dedifferentiation and invasion (Que et al., 1999; Shimonishi et al., 2000). In this study, all four $\mathrm{CC}$ cell lines showed variable expressions of Fas/FasL mRNA, with no correlation to the histological grade of differentiation. However, the SCK cells expressed lower levels of Fas/FasL mRNA than did the ordinary CC cells.

EMT is triggered by oncogenic activation and the primary mode of EMT induction is provided by specific growth factors or extracellular matrix components binding to their cognate cellular receptors. Hepatocyte growth factor and its receptor, Met tyrosine kinase, is one of the predominant modulators of EMT that has been described to date (Birchmeier et al., 1996). Activation of intrinsic kinase activity by their cognate ligands initiates a cascade of cytoplasmic events. This specific transduction pathway involved in EMT consists of Src involvement or the Ras pathway (Boyer et al., 1997). Several transcriptional activators are capable of controlling the EMT process. For example, Fos induces an EMT process by activating a Wnt-like pathway, which is initiated by $\beta$-catenin nuclearization (Eger et al., 2000). Other transcription factors, including the snail family and another snail family slug and the Ets family, are also 
candidates for playing a role in EMT during embryonic life and they may also participate in tumor progression (Batlle et al., 2000). However, the molecular mechanism of EMT whereby tumor cells acquire the phenotype of invasiveness and metastasis is still unclear. Thus, the establishment of sarcomatoid CC cell lines and their genetic analysis may provide us with new information about EMT and the progression of CC.

Vimentin positive cancer cells seem to undergo an EMT event whereby the markers of epithelial differentiation are reduced or even lost and a vimentin expression is acquired (Hendrix et al., 1997). VIM alone was recently shown not to be sufficient to confer the invasive metastatic phenotype (Hendrix et al., 1997). Wnt glycoproteins have been implicated in EMT and also in the diverse processes during embryonic patterning in metazoa. They signal through frizzled-type seventransmembrane-domain receptors to stabilize $\beta$ catenin. Wnt signaling is antagonized by the extracellular Wnt inhibitor DKK1 (Wu et al., 2000). Unexpectedly, the over-expression of $D K K 1$ was found in SCK cells. Thus, its role should be further clarified. Up-regulation of lactate dehydrogenase (LDH) ensures an efficient anaerobic/glycolytic metabolism for tumor cells and reduces dependence on oxygen (Koukourakis et al., 2005). Expressions of mammalian LDHA and LDHB are regulated tissue-specifically during individual development, thus the alterations in serum LD isoenzyme pattern could serve as indicators of pathological involvement and cancer development. The levels of LDHB were specifically elevated in lung cancer patients and progressively increased with the clinical stage of non-small cell lung cancer (Chen et al., 2006). The expression of UCHL1 is closely associated with the advanced stages of lung cancer and with the invasive colorectal cancer (Hibi et al., 1999; Yamazaki et al., 2002). Consistently, our data showed that the upregulations of LDHB and UCHL1 were closely correlated with CC dedifferentiation.

Non-sarcomatous Choi-CK cells express more cytoskeletal structure genes than do sarcomatous SCK cells. The cholangiocarcinoma specific antigens KRT7 and KRT19 were preferentially expressed in the Choi-CK cells, which was consistent with the previous immunohistochemical findings (Wu et al., 1996). Cell growth-related genes, including EGFR, BST2, CCND, and AREG, are also over-expressed in these cells. The EGFR expression has been believed to contribute to the tumor progression of CC (Ito et al., 2001). However, the SCK cells expressed less EGFR than did the other carcinomatous CC cells, and so the dedifferen- tiation seems to rather be associated with the down-regulation of EGFR. ANXA8 is a calciumdependent phospholipid-binding protein that was previously identified as a blood anticoagulant, based on in vitro studies, and it may have a role in the signal transduction pathway in acute promyelocytic leukemia cells (Sarkar et al., 1994). The present results showed that the ANXA8 expression was down-regulated in SCK cells. The expressions of S100P and GPX1 were also decreased according to $C C$ dedifferentiation.

In the recent studies of various cancers, expression arrays have provided insights that were difficult to obtain when single genes or pathways were studied in the past. In the present study, the microarray data was in accordance with the results from both the Northern blotting analysis and the immunohistochemistry. Thus, we recognized the sarcomatous change/EMT-related gene expression profile in CC cells with the sarcomatous phenotype. Some of this data confirmed previous knowledge whereas some of the other data is novel. Some of these novel genes may show promise as clinical markers that are significantly up- or downregulated in sarcomatoid or carcinomatous CC, and they may prove to be additional targets for new strategies to effectively treat cancer.

\section{Methods}

\section{Cell cultures, tumorigenicity and histopathological examination}

Four CC cell lines were grown in DMEM supplemented with $10 \%$ FBS and $1 \%$ antibiotics-antimycotics in a $5 \%$ $\mathrm{CO}_{2}$ air conditioned $\left(37^{\circ} \mathrm{C}\right)$ incubator as described previously (Kim et al., 2001). Four- to six-week old female BALB/c nude mice were purchased from the animal breeding laboratory at Korea Research Institute of Bioscience and Biotechnology (Daejeon, Korea). All mice were group-housed under conditions of constant light cycle (12 $\mathrm{h}$ light/12 $\mathrm{h}$ dark) and fed ad libitum access to sterilized food and water. The animal protocols used were approved by the Institutional animal Care and Use Committee of Chonbuk National University Hospital. To confirm their tumorigenicities and morphological characteristics, the four human CC cell lines (SCK, JCK1, Cho-CK and Choi CK) were xenografted to 4 - to 6 -week-old female athymic nude mice. The JCK1 cells were derived from the original JCK cells and morphologically worse differentiated than the original cells. The cells $\left(0.5-1 \times 10^{7}\right)$ in $0.2 \mathrm{ml}$ culture medium were injected subcutaneously into the flanks of mice. When the subcutaneous tumors reached a diameter of $1 \mathrm{~cm}$ or more, the mice were sacrificed. The subcutaneous tumors were then processed for light microscopy and they were subcultured. The tumors that arose from the xenografts were excised, fixed in $10 \%$ formaldehyde solution and embedded in paraffin for histological examination. 
The sections were stained with hematoxylin and eosin. Immunohistochemistries for differentially expressed genes were performed in the xenotransplanted masses of all four SCK, JCK, Cho-CK, and Choi-CK cells. The endogenous peroxidase activity was blocked with using methanol/ hydrogen peroxide, and after this the tumor tissues were stained by an avidin-biotin-complex immunoperoxidase method with using a commercially available kit (Vector, Burlingame, CA) and antibodies that recognized vimentin (VIM), carcinoembryonic antigen (CEA), alpha- fetoprotein (AFP), albumin, fibrinogen, epithelial membrane antigen (EMA) or epithelial keratin (KRT7, KRT19 and KRT20) (Dako, Copenhagen, Denmark). The immunoperoxidase reaction was then developed with aminoethylcarbazole (Sigma, St. Louis, MO).

\section{Detection of $p 53$ mutations}

Four regions of the p53 gene were amplified from genomic DNA extracts with p53-specific primers. The genomic DNA was extracted and mixed with $10 \mathrm{pmole} / \mu \mathrm{l}$ of forward and reverse primers, buffer and Taq polymerase (2.5 U, Takara, Shiga, Japan). The conditions of PCR were 30 cycles of amplification through denaturation at $95^{\circ} \mathrm{C}$ for $1 \mathrm{~min}$, annealing at an appropriate temperature $\left(59-69^{\circ} \mathrm{C}\right)$ for $30 \mathrm{~s}$ and then extension at $72^{\circ} \mathrm{C}$ for the proper time, respectively. For cDNA sequencing, one $\mu g$ of total RNA was reverse-transcribed with the random decamers of a Retroscript kit (Ambion, Austin, TX). PCR of the cDNA was performed as described above. Direct sequencing was performed by the dideoxy chain termination reaction according to the manufacturer's method. The primers for genomic and cDNA sequencing are described in Supplemental Data Table S1.

\section{Detection of the FHIT gene expression}

The total RNA was extracted from the cells with using Tri Reagent (Molecular Research Center Inc. Cincinnati, OH) and following the manufacturer's instructions. The mRNA was reverse transcribed with oligo $d(T) 15$ primers (Boehringer Mannheim, Mannheim, Germany) to prepare singlestranded cDNA. Two different PCR assays were used to assess the status of the FHIT gene transcript (Supplemental Data Table S1). The first was based on the previously reported nested PCR approach (Ohta et al., 1996). Using the $5 \mathrm{U} 2$ primer, the 3D2 primer, $100 \mu \mathrm{M}$ of each $\mathrm{dNTP}, 10 \times$ PCR polymerase mix and 1 unit Advantage Taq polymerase (Clontech, Palo Alto, CA), the PCR reaction was cycled 25 times in a Perkin-Elmer thermal cycler (model 9700). One $\mu \mathrm{l}$ of a 20-fold dilution was then used in a subsequent nested PCR assay with using the primers $5 \mathrm{U} 1$ and 3D1. Analysis of the FHIT gene transcript was repeated with using another set of primers MUR5 and RP23 (Thiagalingam et al., 1996). The primer MUR5 partially overlaps the primer $5 U 1$ in exon 3 , and the primer RP2 partially overlaps primer 3D2 in exon 10. The PCR products were electrophoresed on $2 \%$ agarose gels (FMC Bioproducts, Rockland, ME).

\section{Fas and FasL mRNA expression}

The mRNA was reverse transcribed with using oligo $d(T) 15$ primers (Boehringer Mannheim) to prepare the single- stranded CDNA, and this was followed by PCR amplification of the Fas mRNA or the FasL mRNA. Amplification was performed for 30 cycles for $\beta$-actin as an internal control and for Fas in a thermal cycler (Perkin Elmer). Each cycle consisted of $1 \mathrm{~min}$ of denaturation at $94^{\circ} \mathrm{C}, 1$ min of annealing at $57^{\circ} \mathrm{C}$ and $1 \mathrm{~min}$ of extension at $72^{\circ} \mathrm{C}$. The sequences of primers used were as follows, Fas (forward: 5'CGGAGGATTGCTAACAAC3', reverse: 5'TTGGTATTCTGGGTCCG3') (Panayiotidis et al., 1995) and $\beta$-actin (forward: 5'CGTTCTGGCGGCACCACCAT3', reverse: 5'GCAACTAAGTCATAGTCCGC3') (Wong et al., 1994). FasL RT-PCR amplification was done for 35 cycles. The sequences of the Fas- $L$ primers are: forward 5 'CAAGTCCAACTCAAGGTCCAT3' (nt 610-630, NM_000639.1) and reverse 5'AACGTATCTGAGCTCTCTCTG3' (nt 935955) (Mita et al., 1994). The PCR conditions consisted of 1 min of denaturation at $94^{\circ} \mathrm{C}, 1 \mathrm{~min}$ of annealing at $55^{\circ} \mathrm{C}$ and $1 \mathrm{~min}$ of extension at $72^{\circ} \mathrm{C}$. The PCR products were analyzed by electrophoresis on $1.2 \%$ agarose gels.

\section{Northern blot analysis}

$5 \times 10^{6}$ cells were harvested by treatment of TrypsinEDTA and they were washed in cold PBS. The total RNA was isolated using an Rneasy mini kit (Qiagen) according to the manufacturer's protocol. The total RNA, a 20 $\mu \mathrm{g} / \mathrm{sample}$, was separated on $1 \%$ agarose gels in $1.8 \mathrm{M}$ formaldehyde and then the RNA was transferred to membranes. The blots were hybridized overnight with a 2 $\times 10^{6} \mathrm{cpm} / \mathrm{ml} \mathrm{cDNA}$ probe labeled with $\left.{ }^{32} \mathrm{P}\right] \mathrm{dCTP}$ (NEN, Boston, MA) by randompriming; the blots were washed and then exposed to x-ray film at $-70^{\circ} \mathrm{C}$, as described previously (Yu et al., 2007). The expressed levels of each gene were calculated by normalizing them against the level of $18 S$ rRNA.

\section{Cell lysis and immunoblotting}

The cells were lysed in a buffer containing $50 \mathrm{mM}$ Tris- $\mathrm{HCl}$ $(\mathrm{pH}$ 8.0), $150 \mathrm{mM} \mathrm{NaCl}, 1 \%$ Triton X-100, $5 \mathrm{mM}$ EDTA, 5 $\mathrm{mM}$ ethylene glycol-bis ( $\beta$-aminoethyl ether) N,N,N',N'tetraacetic acid, $10 \mathrm{mM} \mathrm{NaF}, 1 \mathrm{mM} \mathrm{Na} V_{3} \mathrm{O}_{4}, 1 \mathrm{mM} \mathrm{PMSF}$, $2 \mu \mathrm{g} / \mathrm{ml}$ leupeptin, $1 \mathrm{mM}$ pepstatin and $1 \mu \mathrm{g} / \mathrm{ml}$ aprotinin. Thirty $\mu \mathrm{g}$ of each cell lysate was separated by SDS-PAGE and this was was transferred to Hybond membranes (Amersham Pharmacia Biotech, Uppsala, Sweden). The membranes were blocked with $5 \%$ skim milk and they were then incubated with the designated primary antibodies, and the signals were detected using an ECL Western blotting kit (Amersham Pharmacia Biotech). Mouse anti-p53 (DO-1) monoclonal and rabbit p21 (C-19) polyclonal antibodies were purchased from Santa Cruz Biotechnology, Inc. (Santa Cruz, CA).

\section{Preparation of the florescence-labeled cDNA and the microarray hybridization}

The two sets of cDNA microarrays (14k and 4.6k) used in this study were made by $21 \mathrm{C}$ Frontier the Center for Functional Analysis of Human Genome (Korea Research Institute of Bioscience and Biotechnology, Daejon, Korea) 
and Macrogen, Ltd. (Seoul, Korea). The fluorescencelabeled cDNA probes were made from $100 \mu \mathrm{g}$ of total RNA for each tumor cell line by oligo(dT)-primed polymerization with using SuperScript II reverse transcriptase (Invitrogen Co., Carlsbad, CA). The reaction was carried out in a final volume of $50 \mu \mathrm{l}$ as described previously (Yu et al., 2007). Fluorescent nucleotides Cy5- dUTP and Cy3-dUTP (Amersham) were used at $0.2 \mathrm{mM}$. The nucleotide concentrations were $1 \mathrm{mM}$ for the dGTP, dATP and dCTP and $0.4 \mathrm{mM}$ dTTP. Two hundred units of Superscript II was added at the beginning of the labeling reaction that was incubated at $42^{\circ} \mathrm{C}$. Two hundred units more were added after $1 \mathrm{~h}$ and the reaction was continued for a further $1 \mathrm{~h}$. The Cy5 and Cy3 probes were mixed and the probe volume was reduced to $30 \mu \mathrm{l}$ using a Microcon 30 (Millipore, Bedford, MA). The purified and concentrated fluorescence-labeled cDNAs from the experimental samples were boiled for $5 \mathrm{~min}$, and a hybridization mixture was prepared in a final volume of $100 \mu$ l that contained blocking reagents in sodium saline citrate (SSC)/SDS solution and was mounted on the microarray slides. After placing a coverslip on the slide, hybridization was performed at $65^{\circ} \mathrm{C}$ for $15 \mathrm{~h}$ in a hybridization cassette (TeleChem, Sunnyvale, CA). The slides were washed with $1 \times$ SSC / $0.1 \%$ SDS for $15 \mathrm{~min}$ at $55^{\circ} \mathrm{C}$ twice and with $0.1 \times \mathrm{SSC} / 0.1 \%$ SDS for $15 \mathrm{~min}$ at $55^{\circ} \mathrm{C}$ twice, and then they were washed again in $0.1 \times$ SSC for $10 \mathrm{~min}$ at room temperature. The slides were dried by a brief spin at $500 \mathrm{rpm}$ for $1 \mathrm{~min}$ and then they were immediately subjected to image processing.

\section{Imaging and image analysis}

The fluorescence intensities generated by the Cy5 or Cy3 immobilized at the target sequence on the microarray slides were measured by a laser confocal microscope scanning system ScanArray 4000XL (GSI Lumonics, Billerica MA). The two fluorescent images (Cy5 and Cy3) were scanned separately and they were stored for further image analysis. The color images were generated by arbitrarily assigning experimental intensity values into the red channel and the reference intensity values into the green channel and vice versa. The signals from each immobilized cDNA target on a microarray slide were localized and the expression ratio between the experimental samples and the reference (the Cy5/Cy3 ratio) was determined with using ImaGene 4.2 (BioDiscovery, Los Angeles, CA). The fluorescence intensities of Cy5 and Cy 3 for each target spot were adjusted so that the median Cy5 and Cy3 intensities of all the spots for each slide were equal. The entire hybridization experiments and image analysis were repeated after swapping dyes.

\section{Data analysis}

To assess the correlation of the intensity value for each cDNA between the sarcomatoid CC cells and the nonsarcomatoid CC cells, scatter plots were used and a linear relationship was measured in log space. To determine the significance of the gene expression changes, we used the Significance Analysis of Microarray (SAM) method (Tusher et al., 2001). Briefly, the SAM method computes a score for each gene that measures the difference of the mean log- ratio from zero with using modified one-sample $t$-statistics. The false discovery rate (FDR) was calculated from the order statistics obtained by randomly multiplying the log-ratios by +1 or -1 with equal probability. The $\Delta$ value, which sets the minimum difference between observed and expected scores, was set to 0.76 , resulting in a median FDR of $2.0 \%$. The list of genes was further filtered by selecting those genes that showed at least a 4-fold change.

\section{Supplemental Data}

Supplemental Data include a Table and can be found with this article online at http://e-emm.or.kr/article/article_files/ SP-41-2-06. pdf.

\section{Acknowledgments}

This work was supported by grants from the Korea Health 21 R\&D Project (A050328), Ministry of Health and Welfare, the 21C Frontier Human Genome Project grant (FG0812-03), Ministry of Science and Technology of Korea, the Program for Cancer Control from the Ministry of Health, Welfare and Family affairs (0620220), and the Research Institute of Clinical Medicine, Chonbuk National University Hospital, Republic of Korea. This work was also supported by a grand to K.Y. Choi from the National R\&D program for Cancer Control, Ministry of Health, Welfare and Family affairs, Republic of Korea (0620200-1).

\section{References}

Ahrendt SA, Nakeeb A, Pitt HA. Cholangiocarcinoma. Clin Liver Dis 2001;5:191-21

Batlle E, Sancho E, Francí C, Domínguez D, Monfar M, Baulida J, García De Herreros A. The transcription factor snail is a repressor of E-cadherin gene expression in epithelial tumour cells. Nat Cell Biol 2000;2:84-9

Birchmeier C, Birchmeier W, Brand-Saberi B. Epithelialmesenchymal transitions in cancer progression. Acta Anat (Basel) 1996;156:217-26

Boyer B, Roche S, Denoyelle M, Thiery JP. Src and Ras are involved in separate pathways in epithelial cell scattering. EMBO J 1997;16:5904-13

Chang WW, Agha FP, Morgan WS. Primary sarcoma of the liver in the adult. Cancer 1983;51:1510-7

Chen Y, Zhang H, Xu A, Li N, Liu J, Liu C, Lv D, Wu S, Huang $L$, Yang $S$, He D, Xiao $X$. Elevation of serum I-lactate dehydrogenase $B$ correlated with the clinical stage of lung cancer. Lung Cancer 2006;54:95-102

D'Errico A, Baccarini P, Fiorentino M, Ceccarelli C, Bonazzi C, Ponzetto A, Scoazec JY, Mancini AM, Grigioni WF. Histogenesis of primary liver carcinomas: strengths and weaknesses of cytokeratin profile and albumin mRNA detection. Hum Pathol 1996;27:599-604

Eger A, Stockinger A, Schaffhauser B, Beug H, Foisner R. Epithelial mesenchymal transition by c-Fos estrogen re- 
ceptor activation involves nuclear translocation of betacatenin and upregulation of beta-catenin/lymphoid enhancer binding factor-1 transcriptional activity. J Cell Biol 2000; 148:173-88

Goodman ZD, Ishak KG, Langloss JM, Sesterhenn IA, Rabin L. Combined hepatocellular-cholangiocarcinoma. A histologic and immunohistochemical study. Cancer 1985;55: 124-35

Hendrix MJ, Seftor EA, Seftor RE, Trevor KT. Experimental co-expression of vimentin and keratin intermediate filaments in human breast cancer cells results in phenotypic interconversion and increased invasive behavior. Am J Pathol 1997;150:483-95

Hibi K, Westra WH, Borges M, Goodman S, Sidransky D, Jen J. PGP9.5 as a candidate tumor marker for non-small-cell lung cancer. Am J Pathol 1999;155:711-5

Ito Y, Takeda T, Sasaki Y, Sakon M, Yamada T, Ishiguro S, Imaoka S, Tsujimoto $M$, Higashiyama $S$, Monden $M$, Matsuura N. Expression and clinical significance of the erbB family in intrahepatic cholangiocellular carcinoma. Pathol Res Pract 2001;197:95-100

Kakizoe S, Kojiro M, Nakashima T. Hepatocellular carcinoma with sarcomatous change. Clinicopathologic and immunohistochemical studies of 14 autopsy cases. Cancer 1987; 59:310-6

Kim DG, Park SY, You KR, Lee GB, Kim H, Moon WS, Chun $\mathrm{YH}$, Park SH. Establishment and characterization of chromosomal aberrations in human cholangiocarcinoma cell lines by cross-species color banding. Genes Chromosomes Cancer 2001;30:48-56

Levine AJ. The p53 tumor-suppressor gene. N Engl J Med 1992;326:1350-2

Mita E, Hayashi N, lio S, Takehara T, Hijioka T, Kasahara A, Fusamoto H, Kamada T. Role of Fas ligand in apoptosis induced by hepatitis $C$ virus infection. Biochem Biophys Res Commun 1994;204:468-74

Oda Y, Katsuda S, Nakanishi I. An autopsy case of hepatic sarcomatoid tumor: immunohistochemical comparison with a sarcomatous component of hepatocellular carcinoma. Pathol Int 1994;44:230-6

Ohta M, Inoue H, Cotticelli MG, Kastury K, Baffa R, Palazzo J, Siprashvili Z, Mori M, McCue P, Druck T, Croce CM, Huebner K. The FHIT gene, spanning the chromosome $3 p 14.2$ fragile site and renal carcinoma-associated $t(3 ; 8)$ breakpoint, is abnormal in digestive tract cancers. Cell 1996;84:587-97

Panayiotidis P, Ganeshaguru K, Foroni L, Hoffbrand AV. Expression and function of the FAS antigen in $B$ chronic lymphocytic leukemia and hairy cell leukemia. Leukemia 1995;9:1227-32

Que FG, Phan VA, Phan VH, Celli A, Batts K, LaRusso NF, Gores GJ. Cholangiocarcinomas express Fas ligand and disable the Fas receptor. Hepatology 1999;30:1398-404

Sarkar A, Yang P, Fan YH, Mu ZM, Hauptmann R, Adolf GR, Stass SA, Chang KS. Regulation of the expression of annexin VIII in acute promyelocytic leukemia. Blood 1994;84:279-86

Savagner $P$, Yamada KM, Thiery JP. The zinc-finger protein slug causes desmosome dissociation, an initial and necessary step for growth factor-induced epithelialmesenchymal transition. J Cell Biol 1997;137:1403-19

Shimonishi T, Isse K, Shibata F, Aburatani I, Tsuneyama K, Sabit H, Harada K, Miyazaki K, Nakanuma Y. Up-regulation of fas ligand at early stages and down-regulation of Fas at progressed stages of intrahepatic cholangiocarcinoma reflect evasion from immune surveillance. Hepatology 2000;32:761-9

Sozzi G, Alder H, Tornielli S, Corletto V, Baffa R, Veronese ML, Negrini M, Pilotti S, Pierotti MA, Huebner K, Croce CM. Aberrant FHIT transcripts in Merkel cell carcinoma. Cancer Res 1996;56:2472-4

Thiagalingam S, Lisitsyn NA, Hamaguchi M, Wigler $\mathrm{MH}$, Willson JK, Markowitz SD, Leach FS, Kinzler KW, Vogelstein $B$. Evaluation of the FHIT gene in colorectal cancers. Cancer Res 1996;56:2936-9

Tusher VG, Tibshirani R, Chu G. Significance analysis of microarrays applied to the ionizing radiation response. Proc Natl Acad Sci USA 2001;98:5116-21

Wong $\mathrm{H}$, Anderson WD, Cheng T, Riabowol KT. Monitoring mRNA expression by polymerase chain reaction: the "primer-dropping" method. Anal Biochem 1994;223:251-8

Wu PC, Fang JW, Lau VK, Lai CL, Lo CK, Lau JY. Classification of hepatocellular carcinoma according to hepatocellular and biliary differentiation markers. Clinical and biological implications. Am J Pathol 1996;149:1167-75

Wu W, Glinka A, Delius H, Niehrs C. Mutual antagonism between dickkopf1 and dickkopf2 regulates Wnt/betacatenin signalling. Curr Biol 2000;10:1611-4

Yamazaki T, Hibi K, Takase T, Tezel E, Nakayama H, Kasai Y, Ito K, Akiyama S, Nagasaka T, Nakao A. PGP9.5 as a marker for invasive colorectal cancer. Clin Cancer Res 2002;8:192-5

You KR, Shin MN, Park RK, Lee SO, Kim DG. Activation of caspase-8 during $\mathrm{N}$-(4-hydroxyphenyl)retinamide-induced apoptosis in Fas-defective hepatoma cells. Hepatology $2001 ; 34: 1119-27$ 